\title{
Metabolism of radiolabelled energy-yielding substrates by rat Sertoli cells
}

\author{
J. A. Grootegoed, R. B. Oonk, R. Jansen and H. J. van der Molen \\ Department of Biochemistry (Division of Chemical Endocrinology), Erasmus University Rotterdam, \\ Rotterdam, The Netherlands
}

\begin{abstract}
Summary. The rates of metabolism in vitro of ${ }^{3} \mathrm{H}-$ or ${ }^{14} \mathrm{C}$-labelled glucose, pyruvate, glutamine and leucine by Sertoli cells from immature rats were estimated. The overall rate of glucose utilization exceeded by far the rates of oxidation of pyruvate (derived from glucose) via the citric acid cycle and glucose metabolism via the oxidative branch of the pentose phosphate pathway. This pattern of glucose metabolism was not markedly altered after stimulation of glucose metabolism by FSH. The rate of oxidation of exogenous pyruvate indicated that the energy yield from glucose metabolism by Sertoli cells could be dependent on the extracellular concentrations of pyruvate and lactate. There is no evidence that a high rate of aerobic glycolysis is of vital importance for Sertoli cells. In medium containing glucose and all amino acids, ${ }^{14} \mathrm{C}$-labelled glutamine and leucine were converted to ${ }^{14} \mathrm{CO}_{2}$ at considerable rates. It was calculated that the oxidation of glutamine and leucine in addition to glucose and fatty acids can yield much of the required energy of Sertoli cells.
\end{abstract}

\section{Introduction}

Sertoli cells from immature rats in vitro metabolize glucose via glycolysis at a high rate, which results in net production of lactate (Jutte, Grootegoed, Rommerts \& van der Molen, 1981; Robinson \& Fritz, 1981). The rate of lactate production is increased by FSH, an important regulator of spermatogenesis in immature rats (Jutte et al., 1982; Mita, Price \& Hall, 1982; Jutte, Jansen, Grootegoed, Rommerts \& van der Molen, 1983). Exogenous lactate is essential to support ATP production by isolated rat spermatogenic cells; ATP is rapidly dephosphorylated when round spermatids are exposed to glucose in the absence of exogenous lactate (Grootegoed, Jansen \& van der Molen, 1986). Glucose metabolism and lactate production by Sertoli cells probably play an important role to maintain the ATP content of the spermatogenic cells in vivo. In this respect, it is relevant to study the metabolism of energy-yielding substrates by Sertoli cells.

Using radiolabelled substrates, it should be possible to obtain information on the regulation of the different pathways which could be involved in the metabolism of these substrates. It has been reported, however, that FSH did not affect glucose metabolism by Sertoli cells when the metabolism of ${ }^{3} \mathrm{H}$ - or ${ }^{14} \mathrm{C}$-labelled glucose was studied (Robinson \& Fritz, 1981). This could indicate that FSH exerts an effect primarily on the mobilization of endogenous pools (glycogen). The activity of glycogen phosphorylase in Sertoli cells is stimulated by FSH (Slaughter \& Means, 1983).

We have therefore investigated the metabolism in vitro of radiolabelled glucose, pyruvate, glutamine and leucine by Sertoli cells from rats.

\section{Materials and Methods}

Materials. The following radiolabelled compounds were purchased from Amersham International PLC, Amersham, Bucks, U.K.: D- $\left[1-{ }^{14} \mathrm{C}\right]$ glucose (sp. act. $50-60 \mathrm{Ci} / \mathrm{mol}$ ); D- $\left[6-{ }^{14} \mathrm{C}\right]$ glucose (sp. act. 
50-60 Ci/mol); D-[5- $\left.{ }^{3} \mathrm{H}\right]$ glucose (sp. act. $10-20 \mathrm{Ci} / \mathrm{mol}$ ); L-[U- $\left.{ }^{14} \mathrm{C}\right]$ glutamine (sp. act. $40 \mathrm{Ci} / \mathrm{mol}$ ); L-[U- $\left.{ }^{14} \mathrm{C}\right]$ leucine (sp. act. $330 \mathrm{Ci} / \mathrm{mol}$ ); and $\mathrm{L}-\left[1-{ }^{14} \mathrm{C}\right]$ leucine (sp. act. $55 \mathrm{Ci} / \mathrm{mol}$ ). Radiolabelled pyruvate $\left(\left[1-{ }^{14} \mathrm{C}\right]\right.$ pyruvate $(\mathrm{sp}$. act. $5-20 \mathrm{Ci} / \mathrm{mol})$ and $\left[2-{ }^{14} \mathrm{C}\right]$ pyruvate (sp. act. $\left.15-20 \mathrm{Ci} / \mathrm{mol}\right)$ ) were purchased from New England Nuclear, Boston, MA, U.S.A.

Collagenase (code CLS) was obtained from Worthington Biochemical Corporation, Freehold, NJ, U.S.A. Follicle-stimulating hormone (NIH-FSH-S13) was a gift from the Endocrinology Study Section, National Institutes of Health, Bethesda, MD, U.S.A. Dibutyryl cAMP (dbcAMP) ( $N^{6}, 2^{\prime}$-0-dibutyryladenosine $3^{\prime}: 5^{\prime}$-cyclic monophosphate) was from Boehringer Mannheim B.V., Mannheim, F.R.G. Phenazine methosulphate ( $N$-methyldibenzopyrazine methyl sulphate salt) was purchased from Sigma Chemical Co., St Louis, MO, U.S.A.

Eagle's minimum essential medium (MEM; with Earle's salts, without glutamine) was obtained from Gibco Europe B.V., Hoofddorp, The Netherlands. The medium was supplemented with penicillin $\left(10^{5}\right.$ units/l), streptomycin $(100 \mathrm{mg} / \mathrm{l})$ and fungizone $(1 \mathrm{mg} / \mathrm{l})$. L-Glutamine (final concentration $2 \mathrm{~mm}$ ) was dissolved and added to the medium shortly before use.

Isolation and incubation of Sertoli cells. Sertoli cells were isolated from 3- or 4-week-old Wistar rats. The rats had been irradiated ( $1.5 \mathrm{~Gy}$ ) in utero at Day 19 of gestation (Beaumont, 1960), and the testicular tubules of these animals contained Sertoli cells but no developing germ cells. The rats were killed by cervical dislocation and the testes were collected and decapsulated at room temperature. The decapsulated testes were treated with collagenase $(10 \mathrm{mg}$ per $6-10$ testes $)$ in $20 \mathrm{ml}$ phosphate-buffered saline (PBS) (Dulbecco \& Vogt, 1954), supplemented with 5.6 mM-glucose. This incubation was performed in a siliconized Erlenmeyer flask $(100 \mathrm{ml})$ placed in a Dubnoff-type shaking water bath $(120$ cycles-min $)$, for $30 \mathrm{~min}$ at $32^{\circ} \mathrm{C}$. During the collagenase treatment large tubule fragments were released from the tissue. These tubules were washed twice in PBS by sedimentation for 2 min at unit gravity, and subsequently incubated for another 30 min under the same conditions in the presence of collagenase. At the end of this second collagenase treatment, the cells from the tubular wall had become dissociated almost completely from the Sertoli cells. The Sertoli cell clusters were separated from most of the tubular wall cells by repeated sedimentation at unit gravity for $2 \mathrm{~min}$ in PBS (five times) and were washed once in MEM. The removal of the tubular wall was observed using Nomarski differential-interference contrast optics. In addition, the Sertoli cell preparations were fixed in ethanol-glacial acetic acid $(3: 1, \mathrm{v} / \mathrm{v})$ and applied to microscope slides. After evaporation of the fixative, a drop of acetic acid ( $40 \%)$ was added, and the nuclei were observed by phase-contrast optics. In these preparations, the different morphology of the nuclei of tubular wall cells and Sertoli cells can be recognized (Oonk, Grootegoed \& van der Molen, 1985). The purity of the Sertoli cell preparations was greater than $94 \%$. The Sertoli cells were incubated in plastic flasks $\left(25 \mathrm{~cm}^{2}\right.$ growth area; $0.6-1.2 \mathrm{mg}$ protein per flask) in $4 \mathrm{ml}$ MEM, under an atmosphere of $5 \% \mathrm{CO}_{2}$ in air at $32^{\circ} \mathrm{C}$. FSH $(0.5 \mu \mathrm{g} / \mathrm{ml})$ or dbcAMP $(0.5 \mathrm{mM})$ were added at the start of the incubations.

Estimation of the metabolism of radiolabelled substrates. During incubation for $18 \mathrm{~h}$, the Sertoli cell clusters had become firmly attached to the growth area of the flasks. The attached cells were washed with PBS and the incubations were continued for $2-4 \mathrm{~h}$ in $2 \mathrm{ml} \mathrm{PBS}$, in the presence of glucose $\left(1 \mu \mathrm{Ci}{ }^{3} \mathrm{H}\right.$ - or ${ }^{14} \mathrm{C}$-labelled glucose; $\left.5.6 \mathrm{~mm}\right)$ or pyruvate $\left(0 \cdot 1 \mu \mathrm{Ci}{ }^{14} \mathrm{C}\right.$-labelled pyruvate; $0.01-1.0 \mathrm{mM}$ ). FSH or dbcAMP were added also during this incubation. The incubations in the presence of the labelled compounds were carried out in closed flasks, under air at $32^{\circ} \mathrm{C}$.

The metabolism of ${ }^{14} \mathrm{C}$-labelled L-glutamine and L-leucine was estimated during incubation of Sertoli cells (from 4-week-old sterile rats) in $2 \mathrm{ml} \mathrm{MEM}$, which contained $5.6 \mathrm{~mm}$-glucose, $2 \mathrm{~mm}$ $\mathrm{L}$-glutamine and $0.4 \mathrm{mM}-\mathrm{L}$-leucine, in the presence of $\mathrm{L}-\left[\mathrm{U}-{ }^{14} \mathrm{C}\right]$ glutamine, $\mathrm{L}-\left[\mathrm{U}-{ }^{14} \mathrm{C}\right]$ leucine, or $\mathrm{L}-\left[1-{ }^{14} \mathrm{C}\right]$ leucine $(0 \cdot 1 \mu \mathrm{Ci})$, in closed flasks under an atmosphere of $5 \% \mathrm{CO}_{2}$ in air.

At the end of the incubations with ${ }^{14} \mathrm{C}$-labelled substrates, the reactions were terminated and $\mathrm{CO}_{2}$ was chased from the medium by injection of $0.2 \mathrm{ml}$ of $1 \mathrm{M}-\mathrm{HCl}$ into the incubation medium and injection of $50 \mu \mathrm{l}$ of $6 \mathrm{M}-\mathrm{NaOH}$ into a small vessel, which contained a piece of filter paper and 
was placed in the neck of the flasks. The ${ }^{14} \mathrm{CO}_{2}$ was trapped by the $\mathrm{NaOH}$ during further incubation for $60 \mathrm{~min}$ at $32^{\circ} \mathrm{C}$. Subsequently, the filter paper was transferred to a liquid scintillation vial containing $0.2 \mathrm{ml}$ water. After addition of $0.5 \mathrm{ml}$ Carbo-Sorb II and $10 \mathrm{ml}$ Pico-fluor 15 (Packard Instrument Company Inc., Downers, Grove, IL, U.S.A.) the amount of radioactivity (d.p.m.) was estimated using an Isocap-300 liquid scintillation counter (Searle Analytic, Des Plains, IL, U.S.A.).

The amount of ${ }^{3} \mathrm{H}_{2} \mathrm{O}$ formed from $\left[5-{ }^{3} \mathrm{H}\right]$ glucose was estimated by mixing $1 \mathrm{ml}$ incubation medium with $0.1 \mathrm{ml} 0.5 \mathrm{M}-\mathrm{HCl}$ and $0.1 \mathrm{ml}$ of $0.05 \%$ merthiolate solution. A portion of this mixture $(0.2 \mathrm{ml})$ was equilibrated with $1 \mathrm{ml}$ of water for $48 \mathrm{~h}$ at $55^{\circ} \mathrm{C}$. The amount of radioactivity in the $1 \mathrm{ml}$ water was counted after addition of $10 \mathrm{ml}$ Picofluor.

All incubations with radioactively labelled substrates were also carried out in the absence of cells, and the data were corrected for these blanks. The production of ${ }^{14} \mathrm{CO}_{2}$ or ${ }^{3} \mathrm{H}_{2} \mathrm{O}$ was expressed as nmol substrate converted, calculated as follows: (d.p.m. in ${ }^{14} \mathrm{CO}_{2}$ or ${ }^{3} \mathrm{H}_{2} \mathrm{O} /$ d.p.m. per $\mathrm{ml}$ medium $) \times(\mathrm{nmol}$ substrate $/ \mathrm{ml}$ medium $)$. The outcome of this calculation was expressed as nmol substrate converted to ${ }^{3} \mathrm{H}_{2} \mathrm{O}$ or ${ }^{14} \mathrm{CO}_{2} / \mathrm{h}$ per mg protein. The amount of protein per flask was measured at the end of the incubations in each individual flask by the method of Lowry, Rosebrough, Farr \& Randall (1951) with bovine serum albumin as standard.

The ${ }^{3} \mathrm{H}$ from $\left[5-{ }^{3} \mathrm{H}\right]$ glucose is lost to water in glycolysis, and the rate of formation of ${ }^{3} \mathrm{H}_{2} \mathrm{O}$ represents the combined rates of flow of glucose through glycolysis and the pentose phosphate pathway. The ${ }^{14} \mathrm{C}$ from $\left[1-{ }^{14} \mathrm{C}\right]$ glucose and $\left[6-{ }^{14} \mathrm{C}\right]$ glucose is incorporated into ${ }^{14} \mathrm{CO}_{2}$ via the citric acid cycle and the oxidative branch of the pentose phosphate pathway. The amount of glucose that was metabolized via the pentose phosphate pathway was calculated as described by Ashcroft, Weerasinghe, Bassett \& Randle (1972) by the equation of Katz \& Wood (1963).

\section{Results}

\section{Metabolism of glucose}

The overall rate of glucose metabolism (formation of ${ }^{3} \mathrm{H}_{2} \mathrm{O}$ ) and the rate of glucose oxidation (formation of ${ }^{14} \mathrm{CO}_{2}$ ) by the isolated Sertoli cells were increased by FSH or dbcAMP (Table 1). Under all incubation conditions, the overall rate of glucose utilization was much higher than the rate of glucose oxidation (Table 1).

Table 1. Effects of FSH and dbcAMP on the metabolism of ${ }^{3} \mathrm{H}$ - or ${ }^{14} \mathrm{C}$-labelled glucose by Sertoli cells from 3- or 4-week-old rats

\begin{tabular}{|c|c|c|c|c|}
\hline & \multicolumn{3}{|c|}{$\begin{array}{c}\text { Substrate converted to }{ }^{3} \mathrm{H}_{2} \mathrm{O} \text { or }{ }^{14} \mathrm{CO}_{2} \\
\text { (nmol/h per mg protein) }\end{array}$} & \multirow{2}{*}{$\begin{array}{l}\text { Glucose metabolized } \\
\text { via the pentose } \\
\text { phosphate pathway } \\
\text { (nmol/h per mg protein }\end{array}$} \\
\hline & D- $\left[5-{ }^{3} \mathrm{H}\right] \mathrm{Glucose}$ & D- $\left[1-{ }^{14} \mathrm{C}\right]$ Glucose & D- $\left[6-{ }^{14} \mathrm{C}\right]$ Glucose & \\
\hline \multicolumn{5}{|c|}{ Sertoli cells from } \\
\hline Control & $52 ; 53$ & $3.4 \pm 0.2$ & $1 \cdot 5 \pm 0.2$ & $0 \cdot 6$ \\
\hline FSH & $201 ; 204$ & $8.8 \pm 0.6$ & $4.4 \pm 0.7$ & 1.5 \\
\hline dbcAMP & $310 ; 347$ & $12 \cdot 6 \pm 1 \cdot 3$ & $7 \cdot 5 \pm 0.8$ & 1.8 \\
\hline \multicolumn{5}{|c|}{$\begin{array}{l}\text { Sertoli cells from } \\
\text { 4-week-old rots }\end{array}$} \\
\hline Control & $157 ; 167$ & $2 \cdot 8 \pm 0.6$ & $1.6 \pm 0.7$ & 0.4 \\
\hline FSH & $260 ; 267$ & $14.9 \pm \quad 1.1$ & $9.6 \pm 0.9$ & 1.9 \\
\hline PMS & $132 ; 144$ & $112.5 \pm 13.1$ & $6.2 \pm 0.6$ & $80 \cdot 2$ \\
\hline
\end{tabular}

The Sertoli cells were incubated for $18 \mathrm{~h}$ in MEM, in the absence or presence of FSH or dbcAMP. Subsequently, the cells were incubated for $4 \mathrm{~h}$ in PBS containing ${ }^{3} \mathrm{H}$ - or ${ }^{14} \mathrm{C}$-labelled glucose $(5.6 \mathrm{~mm}$-glucose), in the continued absence or presence of FSH and dbcAMP. Phenazine methosulphate (PMS; $0 \cdot 1 \mathrm{mM}$ ) was added at the start of the incubations with labelled glucose. The results represent duplicate or triplicate incubations (single values or mean \pm s.d.). 
The unstimulated overall rate of glucose metabolism (formation of ${ }^{3} \mathrm{H}_{2} \mathrm{O}$ ) by Sertoli cells from 3-week-old rats was lower than the rate of metabolism by cells from 4-week-old rats (Table 1). The results presented in Table 1 are from single experiments, because the rats used for the different experiments were not of exactly the same age (range 21-23 or 27-29 days of age). Using four different cell preparations obtained from 3-week-old rats, the rates of ${ }^{3} \mathrm{H}_{2} \mathrm{O}$ production from $\left[5-{ }^{3} \mathrm{H}\right]$ glucose in the absence or presence of FSH were, respectively, $55.4 \pm 7.6$ and $194.0 \pm 53.1 \mathrm{nmol} / \mathrm{h} \mathrm{per} \mathrm{mg}$ protein (mean \pm s.d.) $(P<0.005, t$ test $)$. The ratio of stimulated/control was $3.5 \pm 0.6$.

The rate of oxidation of $\left[1-{ }^{14} \mathrm{C}\right]$ glucose by the isolated Sertoli cells was higher than the oxidation rate of $\left[6-{ }^{14} \mathrm{C}\right]$ glucose (Table 1). This indicates that glucose was metabolized via the oxidative branch of the pentose phosphate pathway. The rate of this metabolism was increased after addition of FSH or dbcAMP (Table 1). Under the different incubation conditions, however, the pentose phosphate pathway did not account for more than $1.2 \%$ of the overall rate of glucose metabolism. When the artificial electron acceptor phenazine methosulphate (PMS) was added to the incubation medium, there was a very high rate of oxidation of carbon-1 of glucose (Table 1).

The present experiments were performed using a glucose concentration of $5.6 \mathrm{~mm}$, which represents saturation conditions (Robinson \& Fritz, 1981). The rate of formation of ${ }^{3} \mathrm{H}_{2} \mathrm{O}$ from $\left[5-{ }^{3} \mathrm{H}\right]$ glucose was constant during incubation for $4 \mathrm{~h}$ (Fig. 1). The amount of ${ }^{14} \mathrm{CO}_{2}$ produced from $\left[6-{ }^{14} \mathrm{C}\right]$ glucose during $2-4 \mathrm{~h}$ of incubation, however, was $\sim 4-8$ times higher than during $0-2 \mathrm{~h}$ (Fig. 1). This increase was only $\sim 1-2$-fold when the PBS (containing $\left[6-{ }^{14} \mathrm{C}\right] \mathrm{glucose}$ ) was replaced at $t=2 \mathrm{~h}$ by fresh PBS (containing $\left[6-{ }^{14} \mathrm{C}\right] \mathrm{glucose}$ ) (not shown).

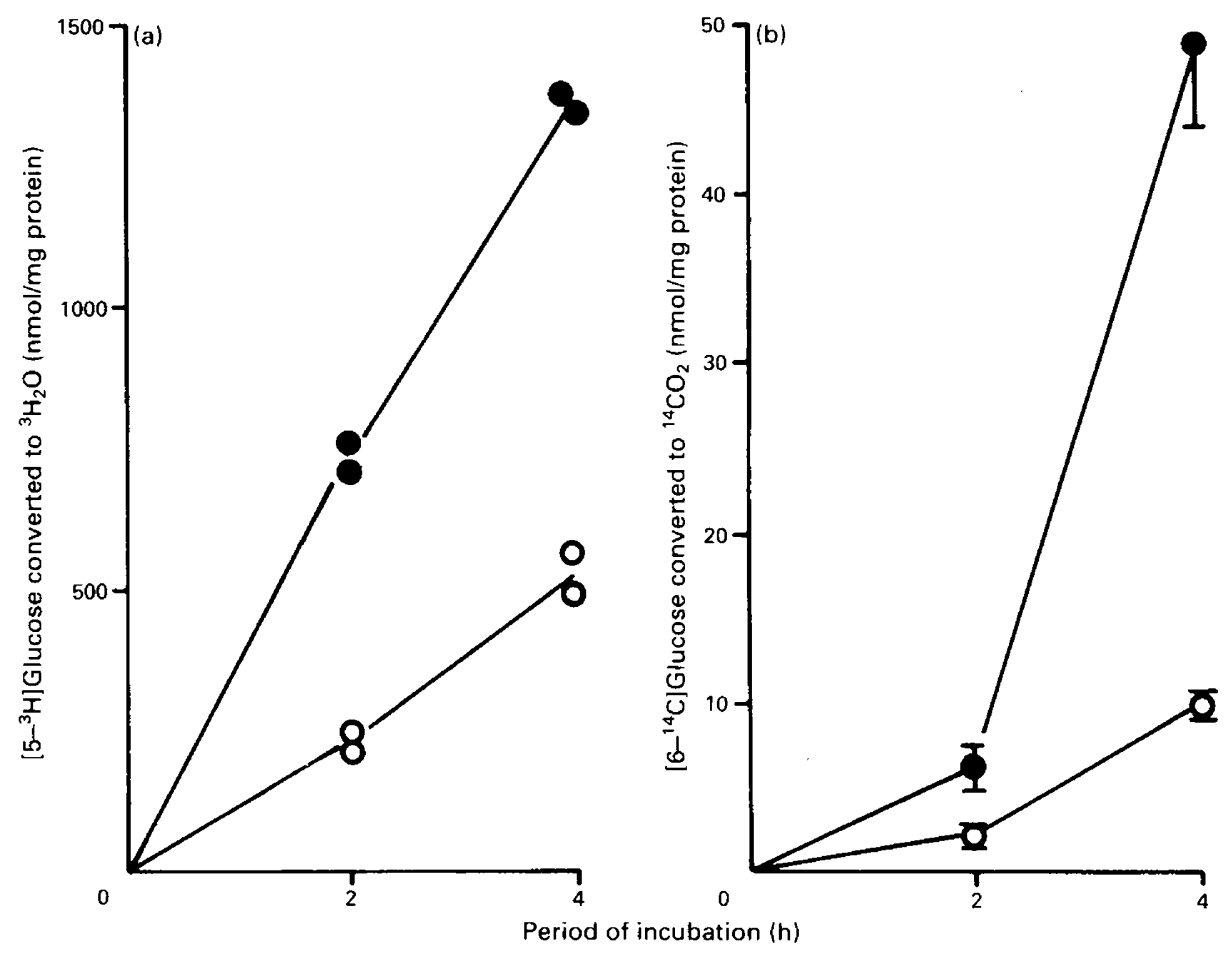

Fig. 1. Metabolism of ${ }^{3} \mathrm{H}$ - or ${ }^{14} \mathrm{C}$-labelled glucose by Sertoli cells from 4-week-old rats, incubated for $18 \mathrm{~h}$ in MEM, in the absence $(O)$ or presence $(O)$ of $0.5 \mathrm{mM}$-dbcAMP. Subsequently, the cells were incubated for 2 or $4 \mathrm{~h}$ in PBS, containing D-[5- $\left.{ }^{3} \mathrm{H}\right]$ glucose or $\mathrm{D}-\left[6-{ }^{14} \mathrm{C}\right] \mathrm{glucose}$ $(5.6 \mathrm{mM}$-glucose), in the continued absence or presence of dbcAMP. The results represent duplicate or triplicate incubations (single values or mean \pm s.d.). 


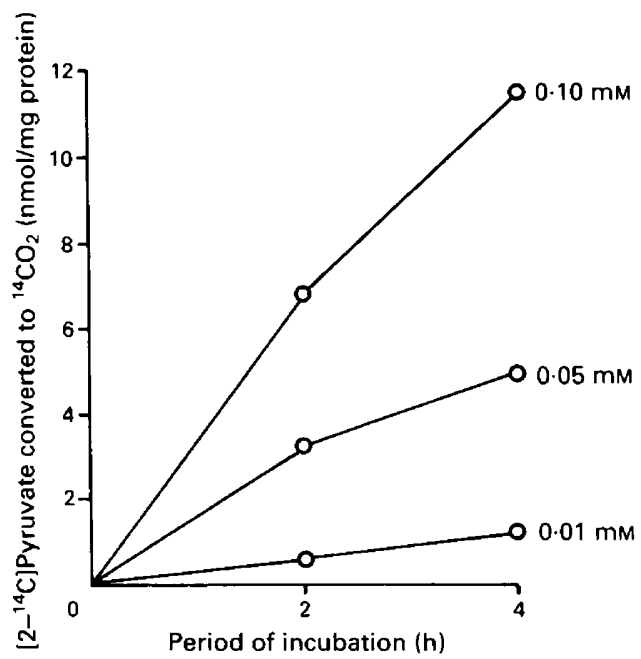

Fig. 2. Oxidation of low concentrations of exogenous ${ }^{14} \mathrm{C}$-labelled pyruvate by Sertoli cells from 4-week-old rats. The cells were incubated for $18 \mathrm{~h}$ in MEM, and then for 2 or $4 \mathrm{~h}$ in PBS, containing $5.6 \mathrm{~mm}$-glucose and $0.01,0.05$ or $0.10 \mathrm{mM}-\left[2-{ }^{14} \mathrm{C}\right]$ pyruvate. The results represent duplicate incubations (mean).

Incorporation of ${ }^{14} \mathrm{C}$ from exogenous $\left[2-{ }^{14} \mathrm{C}\right]$ pyruvate into ${ }^{14} \mathrm{CO}_{2}$ was observed at very low concentrations of exogenous pyruvate, during incubation of Sertoli cells in the presence of $5 \cdot 6$ mM-glucose (Fig. 2).

\section{Metabolism of exogenous pyruvate}

The addition of FSH to the incubation medium resulted in a relatively small increase (less than 2-fold) of the rates of ${ }^{14} \mathrm{CO}_{2}$ formation from $\left[1-{ }^{14} \mathrm{C}\right]$ pyruvate or $\left[2 \cdot{ }^{14} \mathrm{C}\right]$ pyruvate (Table 2). Carbon-1 of pyruvate is directly incorporated into ${ }^{14} \mathrm{CO}_{2}$ in the pyruvate dehydrogenase reaction, whereas carbon-2 of pyruvate is at first incorporated into pools of citric acid cycle intermediates. Consequently, the rate of ${ }^{14} \mathrm{CO}_{2}$ formation from $\left[1-{ }^{14} \mathrm{C}\right]$ pyruvate was higher than that from $\left[2{ }^{14} \mathrm{C}\right]$ pyruvate (Table 2 ).

The effect of FSH on pyruvate oxidation (Table 2) was estimated using medium without glucose, and a stimulatory effect of FSH on the production of endogenous pyruvate (from glucose) could not have interfered with the rate of oxidation of exogenous pyruvate. In the same cell

Table 2. Effect of FSH on the oxidation of exogenous ${ }^{14} \mathrm{C}$-labelled pyruvate by Sertoli cells from 3 -week-old rats

\begin{tabular}{lccc}
\hline & \multicolumn{3}{c}{$\begin{array}{c}\text { Substrate converted to }{ }^{14} \mathrm{CO}_{2} \text { or }{ }^{3} \mathrm{H}_{2} \mathrm{O} \\
\text { (nmol/h per mg protein) }\end{array}$} \\
\cline { 2 - 4 } & {$\left[1-{ }^{14} \mathrm{C}\right]$ Pyruvate } & {$\left[2-{ }^{14} \mathrm{C}\right]$ Pyruvate } & D-[5- $\left.{ }^{3} \mathrm{H}\right]$ Glucose \\
\hline Control & $32 \cdot 8 \pm 4 \cdot 4$ & $11 \cdot 3 \pm 0.5$ & $63 ; 65$ \\
FSH & $55 \cdot 3 \pm 1 \cdot 8$ & $17 \cdot 3 \pm 0.8$ & $252 ; 252$ \\
\hline
\end{tabular}

The Sertoli cells were incubated for $18 \mathrm{~h}$ in MEM, in the absence or presence of FSH, then for $4 \mathrm{~h}$ in PBS containing ${ }^{14} \mathrm{C}$-labelled pyruvate ( $1 \mathrm{~mm}$-sodium pyruvate) or ${ }^{3} \mathrm{H}$-labelled glucose ( $5.6 \mathrm{~mm}$-glucose), in the continued absence or presence of FSH. The results represent duplicate or triplicate incubations (single values or mean \pm s.d.). 
preparation, the overall rate of glucose utilization was stimulated 4-fold by FSH (Table 2). Under these incubation conditions, the rate of $\left[1-{ }^{14} \mathrm{C}\right]$ pyruvate oxidation was $33 \mathrm{nmol} / \mathrm{h}$ per $\mathrm{mg}$ protein (Table 2). However, the overall rate of pyruvate consumption was $118 \pm 5 \mathrm{nmol} / \mathrm{h}$ per $\mathrm{mg}$ protein (mean \pm s.d., quadruplicate incubations; estimated from the amount of pyruvate in the spent incubation medium, as described by Jutte et al., 1983). In addition, exogenous pyruvate was converted to lactate $(85 \pm 4 \mathrm{nmol} / \mathrm{h}$ per $\mathrm{mg}$ protein). Hence, the rate of pyruvate consumption minus the rate of lactate production was $118-85=33 \mathrm{nmol} / \mathrm{h}$ per $\mathrm{mg}$ protein, and equalled the rate of oxidation of ${ }^{14} \mathrm{C}$-labelled pyruvate.

\section{Metabolism of glutamine and leucine}

The present measurements of the rates of oxidation of glucose and pyruvate were carried out during incubation of Sertoli cells for $4 \mathrm{~h}$ in a simple defined medium (phosphate-buffered saline). The saline was supplemented with glucose and/or pyruvate, but did not contain amino acids or other substrates which might be used by Sertoli cells as energy-yielding substrates.

Glutamine oxidation to ${ }^{14} \mathrm{CO}_{2}$ represents conversion of glutamine to glutamate and then to $\alpha$-ketoglutarate, which is followed by oxidation of $\alpha$-ketoglutarate via the citric acid cycle.

$\mathrm{L}-\left[\mathrm{U}-{ }^{14} \mathrm{C}\right]$ Glutamine was converted to ${ }^{14} \mathrm{CO}_{2}$ at a considerable rate during incubation of Sertoli cells in Eagle's minimum essential medium $(6 \cdot 5 \pm 0 \cdot 2 \mathrm{nmol} / \mathrm{h}$ per $\mathrm{mg}$ protein) and this rate was stimulated by dbcAMP $(11.2 \pm 0.5 \mathrm{nmol} / \mathrm{h}$ per $\mathrm{mg}$ protein). The rate of glutamine oxidation to ${ }^{14} \mathrm{CO}_{2}$ was constant for 3 days after isolation of the Sertoli cells $(6.8 \pm 0.2$ and $11.5 \pm 0.5 \mathrm{nmol} / \mathrm{h}$ per $\mathrm{mg}$ protein, in the absence and presence of dbcAMP respectively; mean \pm s.d. for triplicate incubations).

Leucine metabolism involves the formation of 4-methyl-2-oxopentanoate through transamination. The ${ }^{14} \mathrm{C}$ from L- $\left[1-{ }^{14} \mathrm{C}\right]$ leucine is incorporated into ${ }^{14} \mathrm{CO}_{2}$ when 4-methyl-2-oxopentanoate is converted through oxidative decarboxylation to isovaleryl-CoA, which then can be converted to acetoacetate and acetyl-CoA followed by complete oxidation via the citric acid cycle.

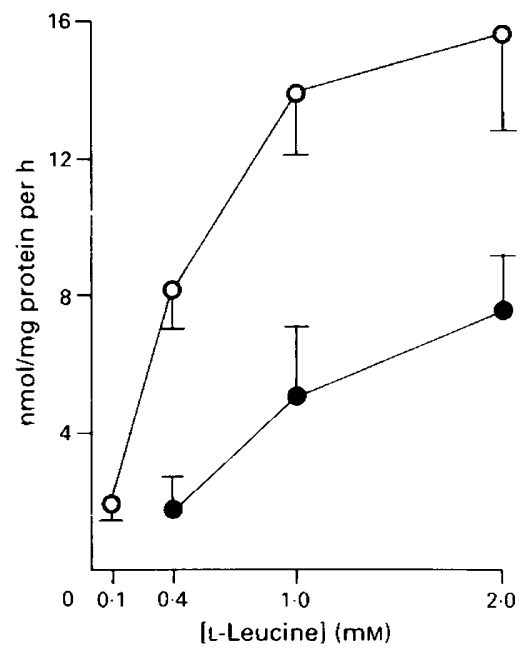

Fig. 3. Conversion of leucine to 4-methyl-2-oxopentanoate and $\mathrm{CO}_{2}$ by Sertoli cells from 4-week-old rats, incubated for $48 \mathrm{~h}$ in MEM. Subsequently, the cells were incubated for $24 \mathrm{~h}$ in MEM, containing different concentrations of $\mathrm{L}-\left[1-{ }^{14} \mathrm{C}\right]$ leucine. The amount of 4-methyl-2oxopentanoate in the spent incubation medium $(\bullet)$ was estimated as described by Taylor \& Jenkins (1966). $\mathrm{CO}_{2}$ production $(O)$ represents the conversion of 4-methyl-2-oxopentanoate to isovaleryl-CoA. The results represent triplicate incubations (mean \pm s.d.). 
In the present experiments, ${ }^{14} \mathrm{CO}_{2}$ was produced from $\mathrm{L}-\left[\mathrm{U}-{ }^{14} \mathrm{C}\right]$ leucine and $\mathrm{L}-\left[1-{ }^{14} \mathrm{C}\right]$ leucine at a ratio of 0.240 .28 (rates of $3.6 \pm 0.8$ and $13.0 \pm 0.9 \mathrm{nmol} / \mathrm{h}$ per $\mathrm{mg}$ protein respectively). Similar rates were observed in the presence of dbcAMP $(2.8 \pm 0.2$ and $11.6 \pm 1.4 \mathrm{nmol} / \mathrm{h}$ per mg protein; mean \pm s.d. of triplicate incubations). At different leucine concentrations, 4-methyl-2oxopentanoate derived from leucine was either converted to isovaleryl-CoA $(70-85 \%)$ or released from the cells (15-30\%) (Fig. 3).

Round spermatids from rats were isolated as described elsewhere (Grootegoed et al., 1984) and incubated for $2 \mathrm{~h}$ in Eagle's minimum essential medium ( $2 \mathrm{mM}$-L-glutamine, $0.4 \mathrm{mM}$-L-leucine). The rates of conversion of $\mathrm{L}-\left[\mathrm{U}-{ }^{14} \mathrm{C}\right]$ glutamine and $\mathrm{L}-\left[\mathrm{U}-{ }^{14} \mathrm{C}\right]$ leucine to ${ }^{14} \mathrm{CO}_{2}$ were $0 \cdot 32 \pm 0.02 \mathrm{nmol}$ and $12 \pm 1 \mathrm{pmol} / \mathrm{h}$ per $4 \times 10^{6}$ cells respectively (means $\pm \mathrm{s} . d$. for triplicate incubations). This equals $\sim 0.5 \mathrm{nmol}$ glutamine and $0.02 \mathrm{nmol}$ leucine $/ \mathrm{h}$ per $\mathrm{mg}$ protein. For comparison, the rate of L-[U- $\left.{ }^{14} \mathrm{C}\right]$ lactate $(3 \mathrm{~mm}-\mathrm{L}-\mathrm{lactate})$ oxidation under these conditions was $12-16 \mathrm{nmol} / \mathrm{h}$ per $4 \times 10^{6}$ cells (Grootegoed et al., 1984).

\section{Discussion}

In the present experiments, the overall rate of glucose metabolism by rat Sertoli cells was increased during incubation in the presence of FSH or dbcAMP. The dbcAMP-stimulated rate of ${ }^{3} \mathrm{H}_{2} \mathrm{O}$ formation from ${ }^{3} \mathrm{H}$-labelled glucose $(300-350 \mathrm{nmol} / \mathrm{h}$ per $\mathrm{mg}$ protein for Sertoli cells from 3-weekold sterile rats) was almost as high as the rate observed by Robinson \& Fritz (1981) for Sertoli cells from 3-week-old intact rats during incubation in the absence of dbcAMP $(\sim 450 \mathrm{nmol} / \mathrm{h}$ per $\mathrm{mg}$ protein). In the experiments reported by Robinson \& Fritz (1981) the Sertoli cells metabolized glucose at a high and possibly maximum rate also in the absence of dbcAMP or FSH, but it is not clear which factor(s) might have initiated or maintained such a high rate. We have shown elsewhere (Oonk et al., 1985) that FSH exerts rapid insulin-like effects on glucose metabolism by Sertoli cells independent of de-novo protein synthesis. The rapid effects of FSH are possibly mimicked by extracellular factors which are not ready catalogued and explicitly controlled.

For the present experiments we have used Sertoli cells from sterile animals to eliminate completely spermatogenic cells. In other experiments we have isolated Sertoli cells from intact rats and found rates of basal and FSH-stimulated lactate production which were in agreement with the present data (results not shown). Furthermore, the basal rate of overall glucose metabolism $\left({ }^{3} \mathrm{H}_{2} \mathrm{O}\right.$ production from ${ }^{3} \mathrm{H}$-labelled glucose) by the isolated Sertoli cells was relatively high using 4-week-old rats as compared to 3-week-old rats. This is in agreement with our previous results (Jutte et al., 1983) on lactate production by Sertoli cells from rats of different ages.

The energy-yield from glucose under the present incubation conditions is limited because only a small amount of the endogenous pyruvate produced from glucose is oxidized via the citric acid cycle (Robinson \& Fritz, 1981; present results). Rather, pyruvate is converted to lactate and both pyruvate and lactate are released from the cells (Grootegoed, Oonk, Jansen \& van der Molen, $1985 \mathrm{~b}$; Jutte et al., 1983). In the present experiments, it was observed that Sertoli cells oxidized exogenous pyruvate at very low concentrations during incubation in the presence of glucose. This could explain that the rate of formation of ${ }^{14} \mathrm{CO}_{2}$ from ${ }^{14} \mathrm{C}$-labelled glucose was markedly increased during $2-4 \mathrm{~h}$ of incubation, when the incubation medium was not renewed at $t=2 \mathrm{~h}$, because the concentration of ${ }^{14} \mathrm{C}$-labelled pyruvate in the medium will be higher during $2-4 \mathrm{~h}$ of incubation than during $0-2 \mathrm{~h}$ of incubation. In other words, the energy yield from glucose metabolism by Sertoli cells in situ is probably dependent on the steady-state extracellular pyruvate and lactate concentrations.

Exogenous pyruvate was converted to lactate, presumably until the pyruvate/lactate ratio had reached equilibrium. This conversion is an NADH-dependent reduction, and the extra reducing equivalents which are expended are most probably generated through mitochondrial metabolism. The rates of oxidation of $\left[1-{ }^{14} \mathrm{C}\right]$ pyruvate and $\left[2-{ }^{14} \mathrm{C}\right]$ pyruvate were stimulated by FSH. It is not 
clear, however, whether this stimulation reflects an increased ATP utilization or could involve a more direct effect on the activity of the pyruvate dehydrogenase complex.

The rate of the oxidative branch of the pentose phosphate pathway is determined by the rate of NADPH oxidation. Under incubation conditions, the pentose phosphate pathway in Sertoli cells is not operating at its maximum rate. This is illustrated by the pronounced effect of phenazine methosulphate (Robinson \& Fritz, 1981; present results). Hormonal signals may accelerate NADPH oxidation, as illustrated by the effects of FSH and dbcAMP on the metabolism of glucose via the pentose phosphate pathway. This effect may be related to the stimulatory effect of FSH on fatty acid biosynthesis (Oonk et al., 1985). The reducing power required in this process is furnished by NADPH.

The present results indicate that effects of FSH on lactate production by Sertoli cells do not reflect mobilization of endogenous storage pools (glycogen). Rather, FSH stimulates the metabolism of exogenous (radiolabelled) glucose. This is indicated also by observations from Hall \& Mita (1984) that the effect of FSH involves an increased rate of glucose transport across the plasma membrane of Sertoli cells. This is not to say, however, that exogenous glucose is the obligatory energy-yielding substrate of Sertoli cells. The observations of Jutte, Eikvar, Levy \& Hansson (1985) have indicated that Sertoli cells (from 19-day-old rats) produce ${ }^{14} \mathrm{CO}_{2}$ from $\left[1-{ }^{14} \mathrm{C}\right]$ palmitate at a rate of about $10 \mathrm{nmol} / \mathrm{h}$ per $\mathrm{mg}$ protein (calculated from the results of Jutte et al., 1985) which could result in a maximum rate of ATP production in the order of $15 \mathrm{nmol} / \mathrm{min}$ per $\mathrm{mg}$ protein. This represents the rate of palmitate oxidation during incubation in the absence of hormones; it has not been reported that hormones or dbcAMP can stimulate palmitate oxidation by Sertoli cells. It can be calculated that an overall rate of glucose metabolism of 50-350 $\mathrm{nmol} / \mathrm{h}$ per $\mathrm{mg}$ protein, and complete oxidation via the citric acid cycle of $1.5-7.5 \mathrm{nmol} / \mathrm{h}$ per mg protein (data from Table 1 for Sertoli cells from 3-week-old rats; basal and dbcAMP-stimulated rates) may result in about 2.5-15 nmol ATP/min per mg protein. The present results therefore support the conclusion from Jutte et al. (1985) that Sertoli cells from immature rats in vitro could extract much energy from lipids as compared to glucose.

It is well known that glutamine is a major energy-yielding substrate for proliferating normal and transformed cells (Zielke, Ozand, Tildon, Sevdalian \& Cornblath, 1978; Reitzer, Wice \& Kennell, 1979). Furthermore, for a number of rat tissues, including the testis, there appears to be a correlation between the activity of mitochondrial NAD $(\mathrm{P})^{+}$-dependent malic enzyme (which may function to convert glutamine-derived malate to pyruvate) and a high rate of cell renewal (Nagel, Dauchy \& Sauer, 1980). The present results indicate that in the spermatogenic epithelium glutamine oxidation may be carried out by the non-proliferating Sertoli cells rather than by spermatogenic cells (round spermatids), although we have not measured glutamine oxidation by actively dividing spermatogonia. Complete oxidation of 6-12 nmol glutamine/h per mg protein by Sertoli cells (see 'Results') could result in the production of about $2-5 \mathrm{nmol} \mathrm{ATP} / \mathrm{min}$ per $\mathrm{mg}$ protein. Therefore, in the presence of glucose and all amino acids a significant amount of energy is derived from glutamine. The present small stimulatory effect of dbcAMP on glutamine oxidation by Sertoli cells may reflect that hormonal signals directly or indirectly stimulate mitochondrial metabolism, as discussed above with respect to the effect of FSH on pyruvate oxidation.

In rat spermatogenic epithelium, the enzyme branched-chain amino acid aminotransferase, that catalyses the conversion of the branched-chain amino acids (valine, leucine, isoleucine) to the corresponding branched-chain $\alpha$-oxo acids, is confined to Sertoli cells (Grootegoed, Jutte, Jansen \& van der Molen, 1983). Sertoli cells, but not spermatocytes and spermatids, can produce 4-methyl-2-oxopentanoate from leucine and this compound is either released from the cells or converted to isovaleryl-CoA. We have described elsewhere (Grootegoed et al., 1985a) that the released 4-methyl-2-oxopentanoate is utilized by spermatocytes and spermatids in a non-energy-yielding pathway. Further oxidation of isovaleryl-CoA in different tissues is not always complete (Buse, Jursinic \& Reid, 1975). A ratio of ${ }^{14} \mathrm{CO}_{2}$ produced from $\mathrm{L}-\left[\mathrm{U}-{ }^{14} \mathrm{C}\right]$ leucine to that from $\mathrm{L}-[1$ ${ }^{14} \mathrm{C}$ ]leucine of 0.6 has been considered compatible with complete oxidation of the leucine molecule 
in muscle tissue (Odessey \& Goldberg, 1972). In the present experiments, a ratio of $0.24-0.28$ was observed, and it is not certain what portion of the metabolic products of leucine is oxidized by Sertoli cells. Complete oxidation of $10-14 \mathrm{nmol}$ isovaleryl-CoA/h per mg protein (see 'Results') could result in a maximum ATP production in the order of $5 \mathrm{nmol} / \mathrm{min}$ per $\mathrm{mg}$ protein. Moreover, Sertoli cells may extract energy from all three branched-chain amino acids (Grootegoed et al., 1983). The formation of isovaleryl-CoA is rate-limiting for leucine oxidation (Buse et al., 1975) and may not be subject to direct hormonal regulation in Sertoli cells, in view of the absence of an effect of dbcAMP under the present incubation conditions. Moreover, the pyruvate dehydrogenase complex which could be a target for hormonal signals does not participate in the further oxidation of isovaleryl-CoA.

In conclusion, the present results show that energy metabolism by Sertoli cells in vitro can involve a number of different substrates and pathways. For Sertoli cells in vivo, the relative importance of the different pathways is likely to be determined by unknown factors including substrate concentrations. For example, the present results indicate that the energy yield of glucose metabolism could be dependent on extracellular pyruvate and lactate concentrations. Furthermore, it is known that the utilization of glucose by cultured cells (proliferating) can be regulated by glutamine, and vice versa (Zielke et al., 1978).

During incubation of Sertoli cells in Eagle's minimum essential medium, FSH and insulin exert rapid and pronounced stimulatory effects on aerobic lactate production (Oonk et al., 1985). These effects could involve an increased rate of carrier-mediated glucose transport (Hall \& Mita, 1984), but may not be driven by the cellular needs for ATP. A strong connection between ATP turnover and glycolysis in tumour cells has been described (Racker, Johnson \& Blackwell, 1983). The contribution of glucose metabolism to maintain a high energy charge in Sertoli cells, however, may be relatively small compared to the energy yield from fatty acids (Jutte et al., 1985) and amino acids (present results). It is therefore possible that in Sertoli cells the rate of glycolysis is not strictly controlled by the rate of ATP turnover. In view of these arguments, it is suggested that a high rate of aerobic glycolysis is probably not of vital importance for Sertoli cells.

This work was supported in part by the Dutch Foundation for Medical Research (FUNGO).

\section{References}

Ashcroft, S.J.H., Weerasinghe, L.C.C., Bassett, J.M. \& Randle, P.J. (1972) The pentose cycle and insulin release in mouse pancreatic islets. Biochem. $J$. 126, $525-532$.

Beaumont, H.M. (1960) Changes in the radiosensitivity of the testis during foetal development. Int. J. radiat. Biol. 2, 247-256.

Buse, M.G., Jursinic, S. \& Reid, S.S. (1975) Regulation of branched-chain amino acid oxidation in isolated muscles, nerves and aortas of rats. Biochem. J. 148, 363-374.

Dulbecco, R. \& Vogt, M. (1954) Plaque formation and isolation of pure lines with poliomyelitis viruses. $J$. exp. Med. 99, 167-182.

Grootegoed, J.A., Jutte, N.H.P.M., Jansen, R. \& van der Molen, H.J. (1983) Hormonal activation of the supporting role of Sertoli cells in spermatogenesis. In Hormones and Cell Regulation, Vol. 7, pp. 299 316. Eds J. E. Dumont, J. Nunez \& R. M. Denton. Elsevier, Amsterdam.

Grootegoed, J.A., Jansen, R. \& van der Molen, H.J. (1984) The role of glucose, pyruvate and lactate in
ATP production by rat spermatocytes and spermatids. Biochim. biophys. Acta 767, 248-256.

Grootegoed, J.A., Jansen, R. \& van der Molen, H.J. (1985a) Intercellular pathway of leucine catabolism in rat spermatogenic epithelium. Biochem. J. 226, 889-892.

Grootegoed, J.A., Oonk, R.B., Jansen, R. \& van der Molen, H.J. (1985b) Spermatogenic cells utilize metabolic intermediates from Sertoli cells. In Gamete Quality and Fertility Regulation, pp. 225-237. Ed. R. Rolland. Elsevier, Amsterdam.

Grootegoed, J.A., Jansen, R. \& van der Molen, H.J. (1986) Effect of glucose on ATP dephosphorylation in rat spermatids. J. Reprod. Fert. 77, 99-107.

Hall, P.F. \& Mita, M. (1984) Influence of folliclestimulating hormone on glucose transport by cultured Sertoli cells. Biol. Reprod. 31, 863-869.

Jutte, N.H.P.M., Grootegoed, J.A., Rommerts, F.F.G. \& van der Molen, H.J. (1981) Exogenous lactate is essential for metabolic activities in isolated rat spermatocytes and spermatids. J. Reprod. Fert. 62, 399-405. 
Jutte, N.H.P.M., Jansen, R., Grootegoed, J.A., Rommerts, F.F.G., Clausen, O.P.F. \& van der Molen, H.J. (1982) Regulation of survival of rat pachytene spermatocytes by lactate supply from Sertoli cells. $J$. Reprod. Fert. 65, 431-438.

Jutte, N.H.P.M., Jansen, R., Grootegoed, J.A., Rommerts, F.F.G. \& van der Molen, H.J. (1983) FSH stimulation of the production of pyruvate and lactate by rat Sertoli cells may be involved in hormonal regulation of spermatogenesis. J. Reprod. Fert. 68 , 219-226.

Jutte, N.H.P.M., Eikvar, L., Levy, F.O. \& Hansson, V. (1985) Metabolism of palmitate in cultured rat Sertoli cells. J. Reprod. Fert. 73, 497-503.

Katz, J. \& Wood, H.G. (1963) The use of $\mathrm{C}^{14} \mathrm{O}_{2}$ yields from glucose-1- and $-6-\mathrm{C}^{14}$ for the evaluation of the pathways of glucose metabolism. J. biol. Chem. 238, $517-523$.

Lowry, O.H., Rosebrough, N.H., Farr, A.L. \& Randall, R.J. (1951) Protein measurement with the Folin phenol reagent. J. biol. Chem. 193, 265-275.

Mita, M., Price, J.M. \& Hall, P.F. (1982) Stimulation by follicle-stimulating hormone of synthesis of lactate by Sertoli cells from rat testis. Endocrinology 110, 1535-1541.

Nagel, W.O., Dauchy, R.T. \& Sauer, L.A. (1980) Mitochondrial malic enzymes. An association between $\mathrm{NAD}(\mathrm{P})^{+}$-dependent malic enzyme and cell renewal in Sprague-Dawley rat tissues. J. biol. Chem. 255, 3849-3854.
Odessey, R. \& Goldberg, A.L. (1972) Oxidation of leucine by rat skeletal muscle. Am. J. Physiol. 223, 1376-1383.

Oonk, R.B., Grootegoed, J.A. \& van der Molen, H.J. (1985) Comparison of the effects of insulin and follitropin on glucose metabolism by Sertoli cells from immature rats. Molec. cell. Endocr. 42, 39-48.

Racker, E., Johnson, J.H. \& Blackwell, M.T. (1983) The role of ATPase in glycolysis of Ehrlich ascites tumor cells. J. biol. Chem. 258, 3702-3705.

Reitzer, L.J., Wice, B.M. \& Kennell, D. (1979) Evidence that glutamine, not sugar, is the major energy source for cultured Hela cells. J. biol. Chem. 254, 2669-2676.

Robinson, R. \& Fritz, I.B. (1981) Metabolism of glucose by Sertoli cells in culture. Biol. Reprod. 24, 10321041.

Slaughter, G.R. \& Means, A.R. (1983) Follicle-stimulating hormone activation of glycogen phosphorylase in the Sertoli cell-enriched rat testis. Endocrinology 113, 1476-1485.

Taylor, R.T. \& Jenkins, W.T. (1966) Leucine aminotransferase. I. Colorimetric assays. J. biol. Chem. 241, 4391-4395.

Zielke, H.R., Ozand, P.T., Tildon, J.T., Sevdalian, D.A. \& Cornblath, M. (1978) Reciprocal regulation of glucose and glutamine utilization by cultured human diploid fibroblasts. J. Cell. Physiol. 95, 41-48.

Received 22 July 1985 